Frank Bahr

\title{
DER RESONANZPUNKT VON COVID-19 AM OHRLÄPPCHEN UND THERAPIEVORSCHLAG
}

\section{The Point of Resonance of COVID-19 is Shown and the Earlobe and a Possible Therapy is Recommended}

\section{Zusammenfassung}

Der Resonanzpunkt für Comirnaty wird vorgestellt und es wird eine mögliche Therapie für das PostCOVID-Syndrom empfohlen.

\section{Schlüsselwörter}

COVID-19, Resonanzpunkt, Laserbehandlung

\section{Summary}

The resonance-point for Comirnaty is shown and a possible therapy for post-COVID-problems is given.

\section{Keywords}

COVID-19, point of resonance,

laser-treatment

D er mRNA-Impfstoff von Biontech (Handelsname Comirnaty, Abb. 1) entspricht weitestgehend der Erbinformation des COVID-19-Virus. Es lag daher nahe zu prüfen, ob in Anlehnung an frühere Vorträge undVeröffentlichungen von Herrn Dr. Ch. Scholtes ein genauer Resonanzpunkt im Ohrläppchenbereich gefunden werden kann.

Ich besorgte mir daher Ampullen dieses Impfstoffes für die Testung und konnte bei der Koordinate N-18 9 Uhr (Rechtshänder rechts) mit der Fortgeschrittenentechnik den Punkt lokalisieren (Abb. 2, Technik: periphere und zentrale Auflage, lokale Suche mit der 3. Ampulle).

\section{Therapieempfehlung für Post-COVID-Syndrom}

- Implantatnadel in den Comirnaty-Punkt

- Interferonpunkt evtl. beidseits oder nicht-dominant in Gold

- Lu-7-Punkt am Ohr oder Körper

- Laser mit Lungenfrequenz $824 \mathrm{~Hz}$ n. Reininger bes. am KG 17

- Kniekehlenlaser (oder Kl 4 Laser über Tibia) mit der Selbstheilungsfrequenz $4625 \mathrm{~Hz} \mathrm{n}$. Bahr

- weitere Punkte prüfen

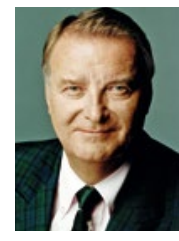

Prof. mult. h.c. China Dr. med. Frank Bahr

Präsident der EATCM

Marsopstr. 25, 81245 München

info@akupunktur.eu

Abb. 1
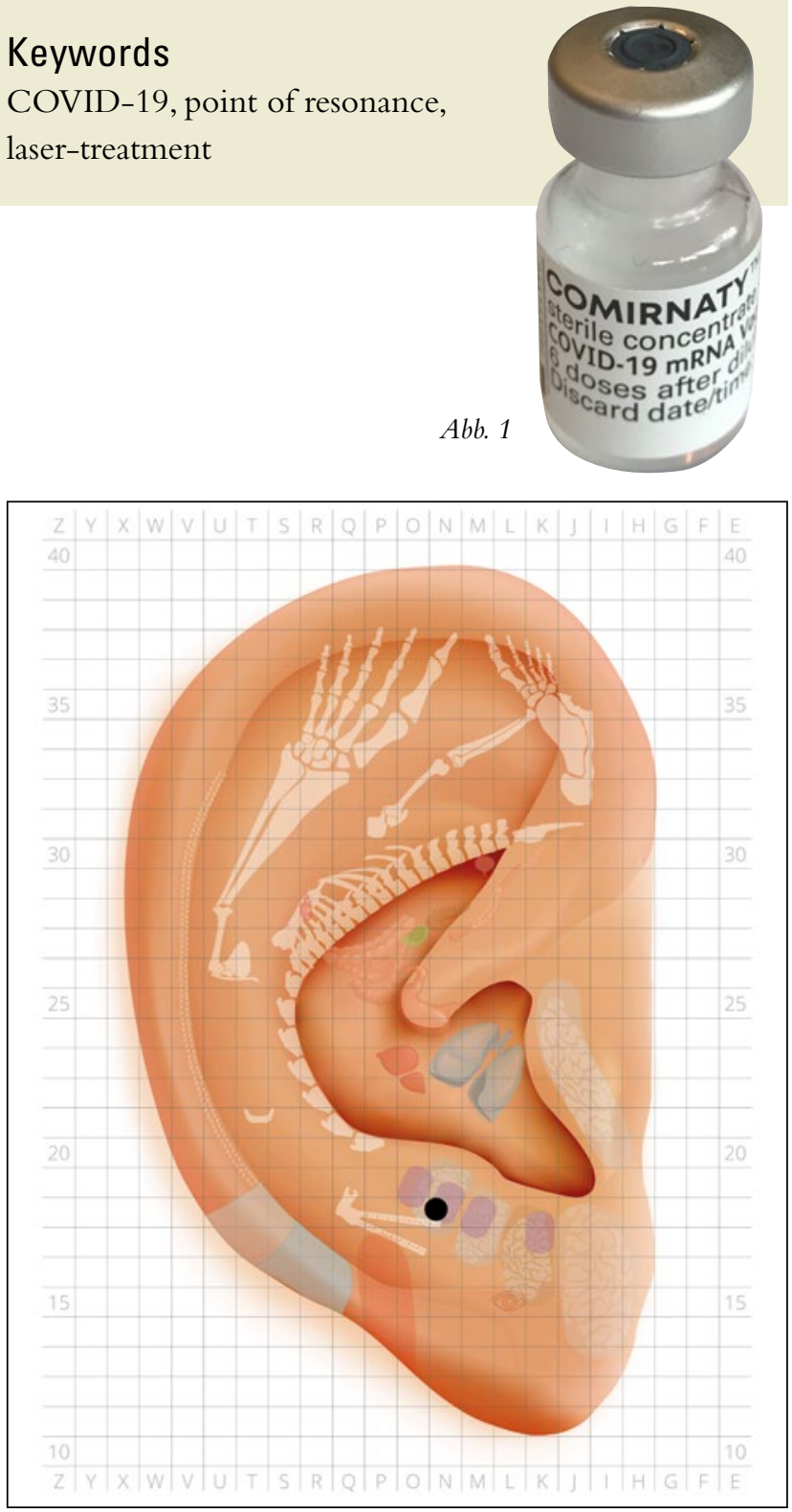